\begin{abstract}
Iranica
Abstracta Iranica Revue bibliographique pour le domaine irano-aryen

Volume 34-35-36 | 2017

Comptes rendus des publications de 2011-2013
\end{abstract}

\title{
Mary Voigt. " Gordion as Citadel and City »
}

\section{Astrid Nunn}

\section{(2) OpenEdition}

Journals

Édition électronique

URL : http://journals.openedition.org/abstractairanica/42817

DOI : 10.4000/abstractairanica.42817

ISSN : 1961-960X

Éditeur :

CNRS (UMR 7528 Mondes iraniens et indiens), Éditions de l'IFRI

Référence électronique

Astrid Nunn, « Mary Voigt. " Gordion as Citadel and City » », Abstracta Iranica [En ligne], Volume 34-35-36 | 2017, document 128, mis en ligne le 30 juillet 2017, consulté le 05 octobre 2020. URL http://journals.openedition.org/abstractairanica/42817 ; DOI : https://doi.org/10.4000/ abstractairanica. 42817

Ce document a été généré automatiquement le 5 octobre 2020.

Tous droits réservés 


\title{
Mary Voigt. « Gordion as Citadel and City "
}

\author{
Astrid Nunn
}

\section{RÉFÉRENCE}

Mary Voigt. « Gordion as Citadel and City », in S. Redford \& N. Ergin (eds), Cities and Citadels in Turkey: from the Iron Age to the Seljuks. ANES Suppl. 40, 2013, p. 161-228.

1 Gordion est surtout connu pour les tumuli et leur riche matériel de l'époque phrygienne. Ce site a toutefois une longue histoire qui remonte au début du second millénaire av. J.-C. L'A nous présente la séquence stratigraphique avec ses divers bâtiments. La strate qui nous intéresse correspond à la « Late Phrygian Period/YHSS 4 " (p. 217-223). Gordion perd certes de son importance avec la conquête achéménide. Mais l'image que nous nous en faisons est biaisée par le fait que son fouilleur R. S. Young ne s'est jamais intéressé à cette période du site. L'A. réévalue les vestiges architecturaux dont beaucoup restèrent utilisés jusqu'en 475 env. Ceci est également valable pour la Inner and Outer Court et le building C2. Des nouvelles structures administratives et résidentielles remplacèrent ensuite les anciennes. Le Mosaic Building, vraisemblablement construit vers la fin du Vème s., la Painted House, d'autres maisons bien construites ainsi que les ateliers de la Southern Lower Town encore fortifiée, prouvent que, même si Gordion avait perdu de son importance politique, il resta un centre de production important et riche. S'y côtoyaient la production locale d'objets en pierre, os et en métal et les biens importés d'Iran (céramique, harnais) et de Grèce (verre et céramique) dans une ville ouverte aux influences du monde méditerranéen entier. 


\section{AUTEURS}

\section{ASTRID NUNN}

Université de Munich 